\title{
COMPETITIVENESS OF HOTEL, RESTAURANT AND TOURISM BUSINESS: FACTORS AND TOOLS
}

\author{
Hanna MASHIKA* \\ Uzhgorod National University, Department of Tourism, 3, Narodna Square, Uzhorod, Ukraine, e-mail: hanna.oby@gmail.com \\ Olha KUDRINA \\ Sumy State Makarenko Pedagogical University, Department of Business Economics and Administration, Sumy, Ukraine, e-mail: o.kudrina@i.ua
}

\author{
Almagul NURGALIYEVA \\ Kazakh University of Technology and Business, Department of Management and Tourism, \\ Nur-Sultan, Republic of Kazakhstan, e-mail: a.nurgaliyeva@gmail.com
}

Oksana BERKOVA

Department of International Tourism and Country Studies, National Aviation University, Kyiv, Ukraine, e-mail: oksana_berkova@ukr.net

Tetiana METIL

Department of Business and Tourism Management, Izmail State University of Humanities, Izmail, Ukraine, e-mail: metil.tetiana@gmail.com

Viktor NOVICHKOV

Odessa National Academy of Food Technologies, Department of Hotel and Restaurant Business, Odesa, Ukraine, e-mail: v_novichkov@i.ua

\begin{abstract}
Citation: Mashika, H., Kudrina, O., Nurgaliyeva, A., Berkova, O., Metil, T., \& Novichkov, V. (2021). COMPETITIVENESS OF HOTEL, RESTAURANT AND TOURISM BUSINESS: FACTORS AND TOOLS. GeoJournal of Tourism and Geosites, 36(2spl), 681-687. https://doi.org/10.30892/gtg.362spl16-698
\end{abstract}

\begin{abstract}
The aim is to find ways to ensure sustainable development and increase the hotel, restaurant, and tourism business's competitiveness. The authors used the correlation-regression dependence of the number of tourists going abroad Y on the income of the population $X$ and Fisher's statistical criterion to check the model's adequacy. Authors proposed the system for ensuring sustainable development and competitiveness of the hotel, restaurant and tourism business. The peculiarity of the proposed system is that it covers all aspects of sustainable development, includes multi-level governing bodies, integrable legal forms of organizations and science, making it possible to form interrelated elements of sustainable development and increase the competitiveness of the hotel and hotel industry, tourism in general. In years of political instability, the number of domestic tourists, with a positive upward trend, is falling sharply, despite rising incomes. Fisher's statistical criterion indicates this model's adequacy: an increase in income of the entire population of Ukraine by UAH $10 \mathrm{mln}$. would lead to the additional appearance of about 8 Ukrainian tourists travelling abroad. The coefficient of elasticity $\operatorname{Ex}(\mathrm{Y})=0.9193$ shows that an increase in the income of the entire population of Ukraine by $1 \%$ would increase the flow of Ukrainian tourists travelling abroad by about $0.9 \%$. The article is devoted to the search for ways to increase the competitiveness of the hotel and restaurant and tourism business. The analysis showed that 2019 was a good year for the entire HRTB. However, the global pandemic COVID-19 in 2020 significantly affected this area: border closures, cancellation of messages between countries, total quarantine, weekend quarantine and other prohibitions. Therefore, the search for a strategy to increase the competitiveness of HRTB facilities in 2020/2021 is the most relevant. The authors proposed a system for ensuring sustainable development and competitiveness of the HRTB. The system covers all aspects of sustainable development.
\end{abstract}

Key words: competitiveness, COVID-19, hotel, restaurant and tourism business (HRTB), hotel, restaurant and tourism organizational structure (HRTOS), sustainable development

\section{INTRODUCTION}

Today, the hotel and restaurant and tourism business (HRTB) play an essential role in the economy of any society. As a result of the development of $\mathrm{HRTB}$, the country receives such benefits as job creation and income growth; attracting investments (including foreign ones); cash flow growth (including foreign currency inflows); GDP growth; increase in tax payments; accelerated economic development of the country (Karimi and Honarvar, 2018; Cherniavska et al., 2020).

With significant potential, the Ukrainian hotel, restaurant and tourism sector could take one of the first places in the world market. But the annual unearned income from international tourism in Ukraine is estimated by experts at \$13.30 billion. Such statistics indicate the non-competitiveness of HRTB Ukraine and not using the country's potential to the full (Bashynska et al., 2019; Robul et al., 2020). The practice of running a hotel, restaurant and tourism business on the territory of Ukraine reveals the problem of introducing advanced technologies of international hospitality, including managerial ones, which is associated with: 1) insufficiently high controllability of all economic processes; 2) insufficient conjugation of the personal and group interests of the participants in the production and implementation processes of the hotel and restaurant direction with the 
interests of society; 3) insufficient transparency of the activities of the managed structures of the field of modern hospitality; 4) the problems of training and employment of specialists in a highly categorized hotel and restaurant direction. Therefore, domestic hotel and restaurant organizational structures should systematically cover the advanced methodology and technology of international hospitality and use the factors and mechanisms of competitive behavior models that would allow, in the conditions of domestic hotel production, to create a more perfect consumer offer that can become a unique competence, and therefore increase the level of competitiveness of the business. Thus, the search for factors that affect the competitiveness of the hotel, restaurant and tourism business, as well as tools to improve is becoming increasingly important.

\section{Theoretical part: competitiveness of hotel, restaurant and tourism business (HRTB): essence, factors, mechanisms \\ 1. Literature review}

A significant contribution to the theoretical study of the essence of the competitiveness of the hotel and restaurant and tourism business was made by Karimi and Honarvar (2018); Prokopenko et al. (2020); Shmygol et al. (2020). The topic of innovative methods of improving the management of enterprises in the service sector (in particular, hotel and restaurant and tourism business) by such scientists as Bashynska et al. (2019); Yakushev (2020). Trends in the hotel and restaurant and tourism business, in particular in Ukraine, were studied by Szewczyk and Lipianin-Zontek (2019); Yukhnovska, (2019); Halkiv et al. (2020); Moyeenudin et al. (2020). Despite the significant interest of scientists in the competitiveness of hotel and restaurant and tourism business, the rapid development of new technologies, information saturation of the environment necessitates a comprehensive study of the prospects of new mechanisms in the management of hotels and restaurants and tourism industries.

\section{Analysis of hotel and restaurant and tourism business in Ukraine}

Before developing methodological recommendations, it is necessary to analyze the current state of the HRTB (Table 1-2).

Table 1. Number of business entities in restaurants and mobile food service in 2010-2019

(compiled by the author based on data from the State Statistics Service of Ukraine)

\begin{tabular}{|c|c|c|c|c|c|c|c|c|c|c|}
\hline Years & 2010 & 2011 & 2012 & 2013 & 2014 & 2015 & 2016 & 2017 & 2018 & 2019 \\
\hline \multicolumn{11}{|c|}{ Restaurants and mobile food service activities } \\
\hline Total, units & 29950 & 24933 & 28142 & 32957 & 37557 & 38345 & 38199 & 38545 & 41860 & 48398 \\
\hline Including natural entities-entrepreneurs, units & 23857 & 18774 & 22441 & 26896 & 32727 & 33633 & 34207 & 34102 & 37283 & 43572 \\
\hline $\begin{array}{l}\text { in } \% \text { to the total of business entities of the } \\
\text { corresponding type of economic activity }\end{array}$ & 79,7 & 75,3 & 79,7 & 81,6 & 87,1 & 87,7 & 89,5 & 88,5 & 89,1 & 90 \\
\hline \multicolumn{11}{|c|}{ Event catering and other food service activities } \\
\hline Total, units & 4635 & 3820 & 4350 & 5077 & 5607 & 5366 & 5293 & 4977 & 5094 & 5415 \\
\hline Including natural entities-entrepreneurs, units & 3981 & 3133 & 3745 & 4488 & 5135 & 4902 & 4900 & 4564 & 4666 & 4991 \\
\hline $\begin{array}{l}\text { in } \% \text { to the total of business entities of the } \\
\text { corresponding type of economic activity }\end{array}$ & 85,9 & 82 & 86,1 & 88,4 & 91,6 & 91,4 & 92,6 & 91,7 & 91,6 & 92,2 \\
\hline \multicolumn{11}{|c|}{ Event catering activities } \\
\hline Total, units & 615 & 512 & 609 & 710 & 790 & 696 & 785 & 734 & 733 & 845 \\
\hline Including natural entities-entrepreneurs, units & 554 & 436 & 521 & 625 & 718 & 636 & 741 & 686 & 680 & 790 \\
\hline $\begin{array}{l}\text { in } \% \text { to the total of business entities of the } \\
\text { corresponding type of economic activity }\end{array}$ & 90,1 & 85,2 & 85,6 & 88 & 90,9 & 91,4 & 94,4 & 93,5 & 92,8 & 93,5 \\
\hline \multicolumn{11}{|c|}{ Other food service activities } \\
\hline Total, units & 4020 & 3308 & 3741 & 4367 & 4817 & 4670 & 4508 & 4243 & 4361 & 4570 \\
\hline Including natural entities-entrepreneurs, units & 3427 & 2697 & 3224 & 3863 & 4417 & 4266 & 4159 & 3878 & 3986 & 4201 \\
\hline $\begin{array}{l}\text { in } \% \text { to the total of business entities of the } \\
\text { corresponding type of economic activity }\end{array}$ & 85,2 & 81,5 & 86,2 & 88,5 & 91,7 & 91,3 & 92,3 & 91,4 & 91,4 & 91,9 \\
\hline \multicolumn{11}{|c|}{ Beverage serving activities } \\
\hline $\begin{array}{c}\text { Total, units } \\
\end{array}$ & 5335 & 4433 & 4859 & 5578 & 6283 & 6670 & 6684 & 6428 & 6604 & 7038 \\
\hline Including natural entities-entrepreneurs, units & 4046 & 3184 & 3806 & 4561 & 5485 & 5918 & 6066 & 5725 & 5867 & 6279 \\
\hline $\begin{array}{l}\text { in } \% \text { to the total of business entities of the } \\
\text { corresponding type of economic activity }\end{array}$ & 75,8 & 71,8 & 78,3 & 81,8 & 87,3 & 88,7 & 90,8 & 89,1 & 88,8 & 89,2 \\
\hline
\end{tabular}

It should be noted that growth is observed in all areas of the restaurant business, albeit insignificant (from 2 to $6 \%$ ). The most massive increase in the number of units is observed in restaurants and mobile food service activities $(6 \%$ over the past 10 years and $12 \%$ over the past 2 years). In the tourism sector, there has also been an increase in both income (by 35\% in 2019), and the number of tourism activities (by 2\% in 2019) and the average number of state workers (by 2\% in 2019), while it is worth noting the efficiency work of subjects: with a slight increase in the number, income increased significantly. For the development of more effective tools, it is necessary to consider in more detail some aspects of the activities of the subjects of the tourism sector (Figure 1 and 2). The figure shows that the primary purpose of travel is leisure, rest (93.2\% in 2018 and $94 \%$ in 2019). Consider the leading countries where Ukrainian tourists go (Figure 2). As you can see, the largest per sent falls on Egypt and Turkey. This situation clearly shows the operation of the Pareto law or the "20/80 Principle" (20\% of the force gives $80 \%$ of the result) (Koch, 1997). Thus, the analysis showed that 2019 was a good year for the entire HRTB.

However, the global pandemic COVID-19 in 2020 significantly affected this area: border closures, cancellation of messages between countries, total quarantine, weekend quarantine and other prohibitions. To survive domestic HRTB entities need to change their strategy. The analysis of the tourism sector showed that Ukrainian tourists prefer a reasonably economic form of recreation; catering is essential, which is why Turkey and Egypt are the most popular destinations. The growth of 
income in the restaurant and hotel sector shows that Ukrainians are increasingly visiting restaurants and cafes. That is why the search for a strategy to increase the competitiveness of HRTB facilities in 2020/2021 is the most relevant.

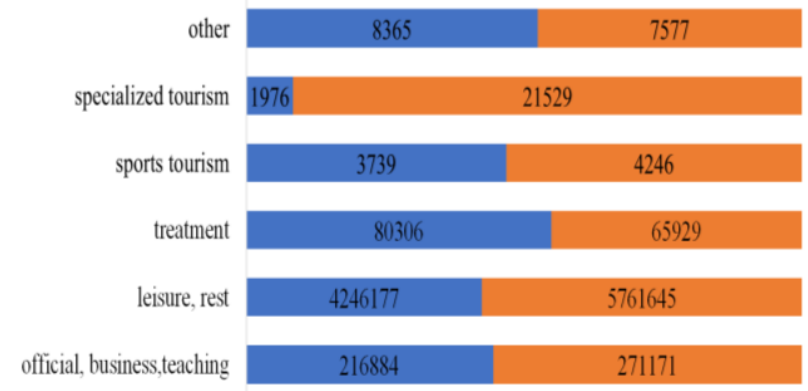

$\begin{array}{lllllllllllll}0 \% & 10 \% & 20 \% & 30 \% & 40 \% & 50 \% & 60 \% & 70 \% & 80 \% & 90 \% & 100 \%\end{array}$

-Number of tourists, 2018 Number of tourists, 2019

Figure 1 - Distribution of tourists by the purpose of travel and types of tourism, 2018-2019 (compiled by the author based on data from the State Statistics Service of Ukraine)

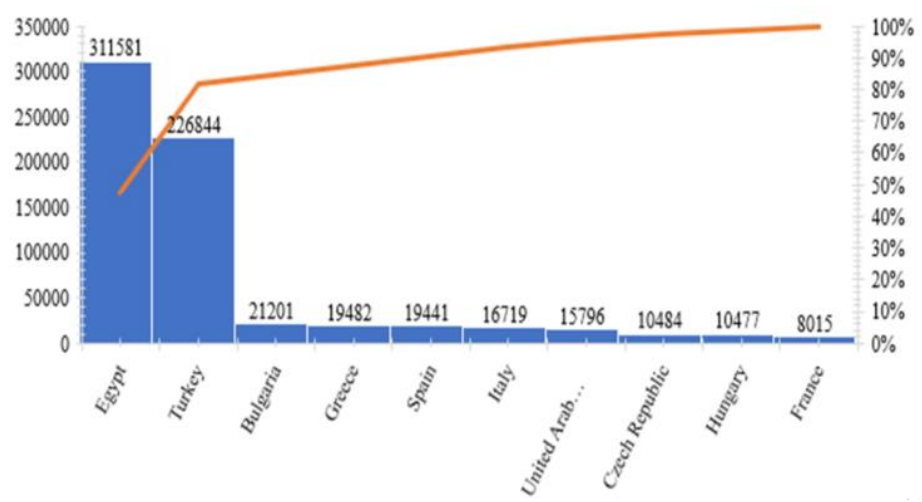

Figure 2 - Distribution of citizens of Ukraine by leading countries, to which they travelled, 2019 (compiled by the author based on data from the State Statistics Service of Ukraine)

Table 2- General characteristics of tourist activities in Ukraine (compiled by the author based on data from the State Statistics Service of Ukraine)

\begin{tabular}{|c|c|c|c|c|c|c|c|c|}
\hline \multirow[b]{3}{*}{ Business entities } & \multicolumn{4}{|c|}{2018} & \multicolumn{4}{|c|}{2019} \\
\hline & \multirow[b]{2}{*}{ Total } & \multicolumn{3}{|c|}{ Including } & & & & \\
\hline & & $\begin{array}{c}\text { tour } \\
\text { operators }\end{array}$ & $\begin{array}{l}\text { travel } \\
\text { agents }\end{array}$ & $\begin{array}{c}\text { entities engaged } \\
\text { in excursion } \\
\text { activities }\end{array}$ & & & & $\begin{array}{c}\text { entities engaged } \\
\text { in excursion } \\
\text { activities }\end{array}$ \\
\hline \multicolumn{9}{|c|}{ Legal entities } \\
\hline Number of tourism entities, units & 1833 & 529 & 1243 & 61 & 1867 & 538 & 1259 & 70 \\
\hline $\begin{array}{l}\text { The average number of full-time } \\
\text { employees, pers. }\end{array}$ & 8934 & 4809 & 3934 & 191 & 9120 & 4826 & 4064 & 230 \\
\hline $\begin{array}{l}\text { Income from the provision of } \\
\text { tourist services (excluding VAT, } \\
\text { excise tax and similar mandatory } \\
\text { payments), thousand UAH }\end{array}$ & 21069268,5 & 20307544,1 & 715185,5 & 46538,9 & 31948701,2 & 31160995,2 & 744002,5 & 43703,5 \\
\hline including from excursion activities & 89220,9 & 37487,8 & 9832,6 & 41900,5 & 113651,0 & 63312,1 & 11602,1 & 38736,8 \\
\hline $\begin{array}{l}\text { The number of commissions, agency } \\
\text { and other rewards, thousand UAH }\end{array}$ & 969551,5 & 306209,8 & 650430,9 & 12910,8 & 1086118,7 & 403278,2 & 677298,6 & 5541,9 \\
\hline $\begin{array}{l}\text { Operating expenses incurred by } \\
\text { the subject of tourist activity for } \\
\text { the provision of tourist services - } \\
\text { total, thousand UAH }\end{array}$ & 17925877,5 & 17125548,9 & 772022,3 & 28306,3 & 19060637,7 & 18067330,5 & 959263,9 & 34043,3 \\
\hline \multicolumn{9}{|c|}{ Individual entrepreneurs } \\
\hline $\begin{array}{l}\text { Number of subjects of tourist } \\
\text { activity, units }\end{array}$ & 2460 & $\mathrm{x}$ & 2322 & 138 & 2797 & $\mathrm{x}$ & 2644 & 153 \\
\hline $\begin{array}{l}\text { The average number of full-time } \\
\text { employees, pers. }\end{array}$ & 2943 & $\mathrm{x}$ & 2808 & 135 & 3345 & $\mathrm{x}$ & 3208 & 137 \\
\hline $\begin{array}{l}\text { of them have higher or secondary } \\
\text { special education in the field of } \\
\text { tourism, pers. }\end{array}$ & 1067 & $\mathrm{x}$ & 1029 & 38 & 1173 & $\mathrm{x}$ & 1144 & 29 \\
\hline $\begin{array}{l}\text { The average number of freelancers } \\
\text { (working for agreements and } \\
\text { external part-timers), pers. }\end{array}$ & 96 & $\mathrm{x}$ & 92 & 4 & 107 & $\mathrm{x}$ & 107 & - \\
\hline $\begin{array}{l}\text { The number of unpaid employees } \\
\text { (owners, founders of the enterprise } \\
\text { and members of their families), pers. }\end{array}$ & 1363 & $\mathrm{x}$ & 1281 & 82 & 1466 & $\mathrm{x}$ & 1374 & 92 \\
\hline $\begin{array}{l}\text { Income from the provision of } \\
\text { tourist services (excluding VAT, } \\
\text { excise tax and similar mandatory } \\
\text { payments), thousand UAH }\end{array}$ & 556652,4 & $\mathrm{x}$ & 501180,1 & 55472,3 & 751474,8 & $\mathrm{x}$ & 688598,9 & 62875,9 \\
\hline
\end{tabular}

\subsection{Concept of ensuring the competitiveness of the HRTB object}

In the modern understanding, the competitiveness of an HRTB facility is its ability to successfully compete with similar organizational units that function in a specific, strictly defined segment of the consumer hotel and restaurant and tourism market. At the same time, competitiveness can also manifest itself in the part of the management processes of the hotel and restaurant and tourist organizational structure (HRTOS), as well as in terms of its departments, hierarchical levels, etc.

The concept of ensuring competitiveness in the field of modern HRTB implies a situational combination of HRTOS competitiveness factors that determine the potential capabilities of this object to compete with similar objects within the 
selected segment of the planned market and is based on the principles of ensuring competitiveness and the laws of strategic management. The competitiveness management process should include the development of a competitive HRTOS strategy based on a comprehensive understanding of the competitive rules that determine the attractiveness and profitability of various types of modern HRTB. The rules of competition combined the interaction of five driving forces of competition and were later called the theory of driving forces of competition, namely:

1) new competitors entering the market;

2) the threat from substitutes;

3) the bargaining power of buyers;

4) the bargaining power of suppliers;

5) the rivalry between competitors operating in the market (Kotler, 1980; Porter, 1980; Prokopenko et al., 2020).

In HRTB, the combined action of the above five forces determines the facility's ability to generate an average return on capital investment in excess of the cost of capital. The total power of these five forces differs depending on the categorization, specific or consumer niche of the hotel industry, and may change as it develops. The practical application of this theory provides an opportunity to identify strategic innovations, the use of which contributes to the maximum increase in HRTOS profits, and its primary goal is to increase the chances of management in finding the necessary strategic innovation in the process of managing the competitiveness of hospitality facilities. The cycle of competitiveness management in the field of modern HRTB should be based on the stages of strategic management, which include mechanisms for stabilizing variable modifications of the foundations of the strategic goal-setting of the hospitality object. Namely:

1) development of the HRTOS strategy;

2) development and implementation of algorithms for adapting the developed strategy to the specific features of HRTOS, functioning in the conditions of the Ukrainian HRTB market;

3) development and use of mechanisms for the implementation of the strategy, reducing the possibility of unfavourable modification of the basic principles of HRTOS.

The HRTB business strategy of an integrated HRTOS management plan should strengthen the position of the facility in the market of competitors and thus ensure the coordination of HRTOS efforts and capabilities aimed at attracting and satisfying potential clientele, successfully competing, achieving global goals, and considering the nuances of the competitive conditions of the hotel market in Ukraine. The process of developing a strategy should be based on a detailed analysis of all possible directions for the development of the hotel and restaurant and hotel industry, as well as based on an analysis of the activities of the leading direct competitors for each categorization and specific segment. Therefore, the strategy algorithm consists in choosing:

1) the general business direction for HRTOS;

2) the categorization and specific segments of the domestic hospitality market being mastered;

3) the served segments of consumers;

4) the methods and methods of hotel competition;

5) the resources involved, 6) the models HRTOS management.

When investing in the domestic hotel and restaurant and hotel business sector, it is necessary to realize the complexity and long-term payback of such enterprises, as well as the fact that before starting to sell a hotel product it is required to bring it to a state of competitiveness in the conditions of domestic production. The experience of international corporations that successfully use the opportunities of establishing their business within the framework of the domestic market shows that the strengths of a successful modern HRTOS are (Figure 3).

At the same time, the experience and knowledge of HRTOS, its

intellectual capital, competitive capabilities, unique skills, strategically valuable assets, market achievements, in the aggregate, will constitute the resource hotel potential, which is extremely necessary for the face of increasing competition in the domestic hotel sector. Success in the competition will also be determined by the number of the above-mentioned resource indicators and the ability of the organizational unit to mobilize them at a time favourable for the business. Thus, the main task of the domestic hotel HRTB should be the transformation of the competitive strengths of the Ukrainian accommodation and catering facilities into a sustainable competitive advantage, as well as the definition of a list of strategic actions that will be able to eliminate the competitive disadvantages of the considered organizational units in the future. Besides, if HRTOS has a significant competitive edge in hospitality sectors where competitors are weak, it will allow it to take the offensive and take the lead.

\section{Practical part: Tools for the competitiveness of hotel and restaurant and tourism business}

2.1 The system for ensuring sustainable development and competitiveness of the hotel, restaurant and tourism business

The analysis showed that right now, the most urgent problem is the survival of the objects of the hotel and restaurant and tourism business by increasing their competitiveness. Taking into account the huge potential of the country, the global pandemic COVID-19, and the insignificant contribution to the economy, a system should be developed to ensure sustainable development of tourism and hospitality in general and the hotel industry in particular (Figure 4).

The key players ensuring the formation, functioning and increasing the competitiveness of the system are tourism business entities, national tour operators, hotel and restaurant entities, state HRT authorities, scientific and educational institutions and associations, unions. Joining efforts and coordinating the actions of players (business, government, public associations and 
non-profit organizations, science) into a single whole contributes to a deep understanding of the industry's problems and the adoption of more effective measures to solve them (Szewczyk and Lipianin-Zontek, 2019).

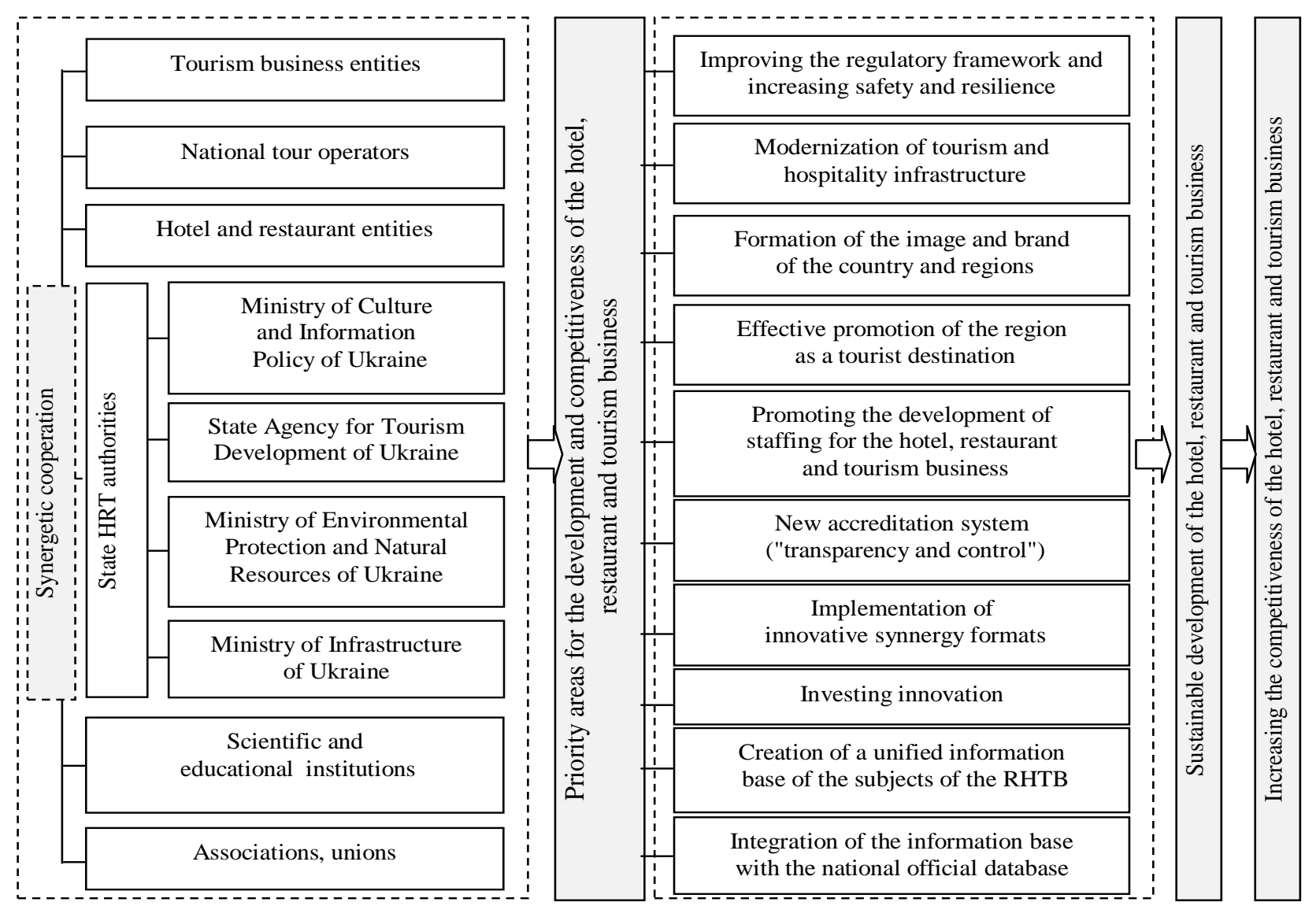

Figure 4. The system for ensuring sustainable development and competitiveness of the hotel, restaurant and tourism business (Source: developed by authors)

This presupposes the formation of elements of a system for ensuring sustainable development and competitiveness of the hotel, restaurant and tourism business based on the elaboration of priority areas for the development and competitiveness.

1) Improving the regulatory framework and enhancing safety and resilience. Laws are the basis for development and must comply with the requirements of a changing economic situation; therefore, it is necessary to develop new conditions, standards and norms that will ensure sustainability in all areas: the legal regulation of energy conservation and renewable (alternative) energy sources, district planning (criteria for reconstruction and site selection and materials for the construction of new hotels and other tourist facilities, taking into account the traditions of local architecture). They also include laws on the basics of tourism, creating a favourable climate for national and foreign investments, on supporting small and medium-sized businesses, promoting innovation and research, on the rights of workers and protecting consumer rights, on ensuring the security of the region.

2) Government authorities, together with relevant organizations, should develop a strategic plan for the modernization of tourism and hospitality infrastructure, including activating and supplying tourist resources with the necessary services (housing and communal services, transport, information, financial, etc.) by the recommended international standards, which, in turn, ensures an increase in demand in the market for enterprises of the hotel industry and contributes to an increase in the quality of service and life of the local population.

3) Formation of the image and brand of the country and regions should be one of the priority directions of the concept of long-term socio-economic development of the country. This vector of development of player relations is aimed not only at creating a positive image, reputation and gaining a larger share of the international market but also at strengthening the country's position in the international arena. It is advisable that the country has an image reflecting its versatility. This can be done with national brands based on aspects such as tourism, export, culture, sports, investment, government, etc. International practice proves that in most cases, tourism is the most common dimension that governments choose to develop a national brand. This contributes to the sustainable dissemination of information and awareness of the region's resources.

4) Cooperation of participants' activities to promote the region as a "renewed tourist destination" at the interregional and international level, allows you to concentrate all resources and use modern marketing tools and achieve a synergistic effect.

5) Qualified and competent personnel is the most critical factor in the successful hotel and restaurant and tourism business and one of the most important reasons for the fluctuations in the quality of this type of service associated with unskilled labour and staff turnover. Coordination of the interaction of players will allow to quickly respond to the market requirements for the qualifications of specialists of various categories and to form state targeted efficiently and commercial staffing programs, including educational programs in universities, as well as advanced training and employee accreditation. 
6) The introduction of a new accreditation system for hotel enterprises implies the application of a unified international classification system for hotels, which must be accredited by regional and local authorities and associations, i.e. it will be aimed not at organizing corruption schemes, but as transparent as possible, but at the same time ensuring control and consumer rights.

7) Innovative formats of the hotel business are aimed at increasing the overall socio-economic and environmental sustainability of HRTB participants, reducing the risks associated with environmental variability, the impact of crises and pandemics. This, in turn, will lead to diversification of the sphere.

8) The cooperation of the players creates a favourable investment and innovation climate for the introduction of new technologies and techniques, affecting all elements and stages of service.

9) The creation of a unified information base of the subjects of the hotel, restaurant and tourism business and its integration with the national database of official data will allow the authorities to monitor the industry, and the enterprises themselves that form this industry - to track and take into account the main trends and prospects for the development of the hotel business. This database will help to objectively assess the real state of activity in the region, which, in turn, will ensure higher management efficiency and optimal results. Combining with such an application as "Diya" will significantly simplify the provision of services to consumers, reduce possible criminogenic factors because the consumer will not take original documents with him on vacation. Moreover, most hotels currently pay from $10 \%$ to $25 \%$ of a foreign company when booking through the Booking resource. The establishment of the commission, for example, at $5 \%$ will not only reduce the tax pressure on the industry but also receive additional financial injections into the national economy.

\subsection{Economic and mathematical modelling}

Based on the statistical data of tourist flows for the period 2000-2019 (Table 3) and the analysis of their dynamics, it is possible to identify the main influencing factors. Using correlation-regression analysis, a number of econometric models of the corresponding dependencies are proposed. MS Excel was used for calculations.

Table 3 - Number of tourists served in 2000-2019 (compiled by the author based on data from the State Statistics Service of Ukraine)

\begin{tabular}{|c|c|c|c|c|c|}
\hline \multirow{2}{*}{ Year } & Number of tourists served by tour & \multicolumn{3}{|c|}{ Including } & \multirow{2}{*}{ Household income } \\
\cline { 3 - 6 } & operators and travel agents, total & incoming (foreign) tourists & outbound tourists & domestic tourists & \\
\hline 2000 & 2013998 & 377871 & 285353 & 1350774 & 86833 \\
\hline 2001 & 2175090 & 416186 & 271281 & 1487623 & 108835 \\
\hline 2002 & 2265317 & 417729 & 302632 & 1544956 & 191946 \\
\hline 2003 & 2856983 & 590641 & 344332 & 1922010 & 211922 \\
\hline 2004 & 1890370 & 436311 & 441798 & 1012261 & 264382 \\
\hline 2005 & 1825649 & 326389 & 566942 & 932318 & 365923 \\
\hline 2006 & 2206498 & 299125 & 868228 & 1039145 & 475200 \\
\hline 2007 & 2863820 & 372455 & 336049 & 2155316 & 625868 \\
\hline 2008 & 3041655 & 372752 & 1282023 & 1386880 & 850232 \\
\hline 2009 & 2290097 & 282287 & 913640 & 1094170 & 897669 \\
\hline 2010 & 2280757 & 335835 & 1295623 & 649299 & 1101015 \\
\hline 2011 & 2199977 & 234271 & 1250068 & 715638 & 1251005 \\
\hline 2012 & 3000696 & 270064 & 1956662 & 773970 & 1407197 \\
\hline 2013 & 3454316 & 232311 & 2519390 & 702615 & 1529406 \\
\hline 2014 & 2425089 & 17070 & 2085273 & 322746 & 1516768 \\
\hline 2015 & 2019576 & 15159 & 1647390 & 357027 & 1772016 \\
\hline 2016 & 2549606 & 35071 & 2060974 & 453561 & 2051331 \\
\hline 2017 & 2806426 & 39605 & 2289854 & 476967 & 2652082 \\
\hline 2018 & 4557447 & 75945 & 4024703 & 456799 & 3248730 \\
\hline 2019 & 6132097 & 86840 & 5524866 & 520391 & 3699346 \\
\hline
\end{tabular}

The table shows that in years of political instability, the number of domestic tourists, with a positive upward trend, falls sharply, despite rising incomes. The table clearly shows the crisis of 2008, when the number of incoming tourists decreased to $0.1 \%$ from the previous year, and the number of outbound increased by $281.5 \%$. The confidence of domestic consumers of tourism products in tourism entities is declining. For a number of statistics, this can be described: a linear econometric model of the dependence of the number of tourists Y served by the subjects of tourist activity of Ukraine on the number of domestic tourists $\mathrm{X}$ (source: developed by authors):

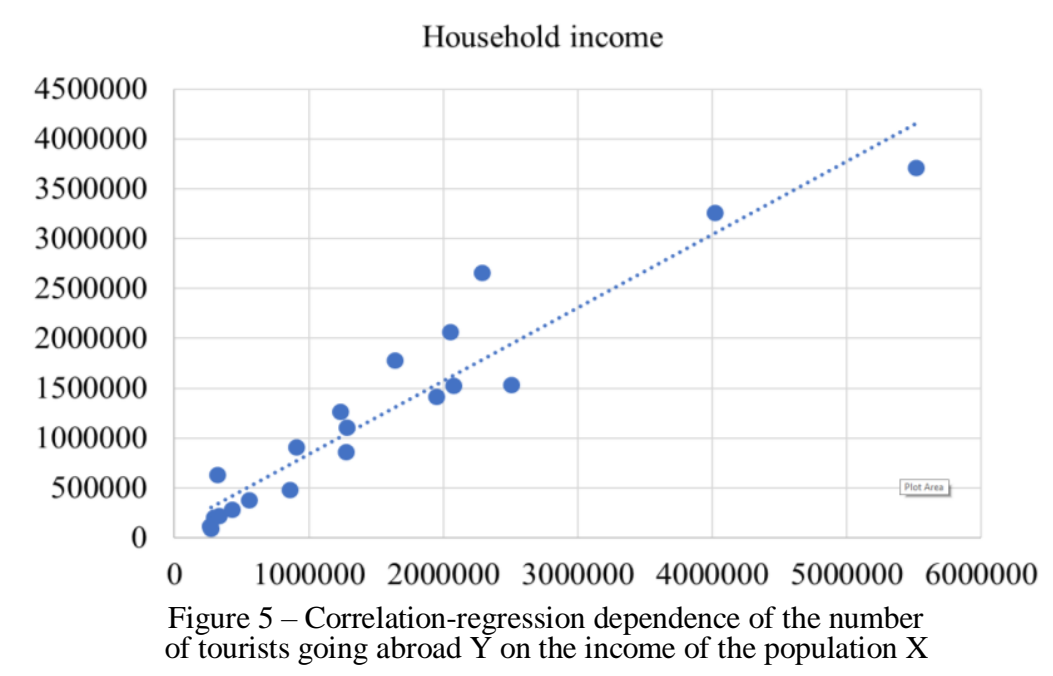

of tourists going abroad $\mathrm{Y}$ on the income of the population $\mathrm{X}$ 
where $\mathrm{Y}$ - the number of tourists served by tourist organizations of Ukraine;

$\mathrm{X}$ - the number of domestic tourists;

$\mathrm{R}^{2}$ - the coefficient of determination, which shows that $77.88 \%$ of the variation of the dependent variable $\mathrm{Y}$ is explained by the independent variable $X$.

The correlation coefficient $r=\sqrt{ } R^{2}=0.8825$ characterizes a fairly high degree of density of the linear relationship between random variables $(X, Y)$. The elasticity $\operatorname{Ex}(y)=(d y / d x) *(x / y)=y^{\prime}(x / y)$ expresses the approximate percentage increase of the function $\mathrm{Y}$, which corresponds to a one percent increase in the argument. The coefficient of elasticity was calculated when the argument (data) was about 0.82 , which means that an increase in the flow of domestic tourists by $1 \%$ would increase the number of tourists served by travel agencies by about $0.82 \%$. The number of Ukrainian tourists travelling abroad $\mathrm{Y}$ increases with the income of the population $\mathrm{X}$ of Ukraine (Figure 5).

For statistical data for 2000-2019 authors proposed linear correlation-regression model:

$$
\mathrm{Y}=0.7333 \mathrm{X}+105644 ; \mathrm{R}^{2}=0.9023, \mathrm{r}=0.9499
$$

The use of Fisher's statistical criterion indicates the adequacy of this model. As we can see from the model, the increase in income of the entire population of Ukraine by UAH 10 million would lead to the additional appearance of about 8 Ukrainian tourists travelling abroad. The coefficient of elasticity $E x(y)=0.9193$ shows that an increase in the income of the entire population of Ukraine by $1 \%$ would increase the flow of Ukrainian tourists travelling abroad by about $0.9 \%$.

\section{CONCLUSION}

The modern market economy is a complex organism, which consists of a wide variety of industrial, commercial, financial and informational structures interacting against the background of a complex system of legal norms of business and united by a single concept - the market. An important concept that describes the essence of market relations is the concept of competition. Competition is a dynamic process that serves to better provide the market with goods and services. In these modern times of uncertainty, crises and pandemics, increasing market competitiveness is not just a development issue, but an essential aspect of survival. Ukrainian hotel, restaurant and tourism business is a unique phenomenon since it differs in its traditions and cultural environment from the hotel markets of Europe, the USA and Asia.

The territory of Ukraine is very diverse, as well as the climate, cultural traditions, historical monuments - a unique combination of these factors forms favourable trends in the development of domestic tourism, as well as worthy participation in the international tourism and hospitality industry.

\section{REFERENCES}

Bashynska, I., Lytovchenko, I., \& Kharenko, D. (2019). Sales tunnels in messengers as new technologies for effective internet-marketing in tourism and hospitality. International Journal of Innovative Technology and Exploring Engineering, 8(12), 594-598. https://doi.org/10.35940/ijitee.L3470.1081219

Cherniavska, O.V., Liu, Y.R., Cherniavska, O.D., Khan, I., \& Zham, O. (2020). Scaling up Chengyu's role in Xi Jinping's government policies concept: From specific Chinese national linguistic constructions up to markers and goals of the geo-economic development strategy. International Journal of Management, 11(5), 185-194. https://doi.org/10.34218/IJM.11.5.2020.018

Halkiv, L., Karyy, O., Kulyniak, I., \& Ohinok, S. (2020). Modeling and forecasting of innovative, scientific and technical activity indicators under unstable economic situation in the country: Case of Ukraine. Communications in Computer and Information Science, 1158, 79-97.

Karimi, T., Honarvar, A. (2018). The Relation of the Sport Tourism with Job Creation, Income and Poverty Reduction and Investment in Tehran. Singaporean Journal of Business Economics and Management Studies, 6(7), 13-20. https://doi.org/10.12816/0048622

Koch, R. (1997). The 80/20 Principle: The Secret of Achieving More with Less. Nicholas Brealey Publishing, 1997, 304.

Kotler, Ph. (1980). Marketing Management: Analysis, Planning and Control, 4th ed., Englewood Cliffs, NJ: Prentice-Hall, 512.

Moyeenudin, H., Lawrence, A., Srivastava, C., \& Suganya, R. (2020). The Inclusive Growth of Hotel and Restaurants with Tourism Sustainability in India. GIS-Business, 15(3), 1430-3663. https://doi.org/10.26643/gis.v15i3

Porter, M.E. (1980). Competitive Strategy: Techniques for Analyzing Industries and Competitors, New York: The Free Press, 385.

Prokopenko, O., Rusavska, V., Maliar, N., Tvelina, A., Opanasiuk, N., \& Aldankova, H. (2020). Digital-toolkit for sports tourism promoting. International Journal of Advanced Research in Engineering and Technology, 11(5), 84-96. https://doi.org/10.34218/IJARET.11.5.2020.0010

Robul, Y., Deineha, O., Prokopenko, M., Novikova, N., Lukianykhina, O., \& Baistriuchenko, N. (2020). Cyber sales as the latest tool for optimizing an enterprise strategy. International Journal of Scientific and Technology Research, 9(2), 5264-5268. http://www.ijstr.org/final-print/feb2020/Cyber-Sales-As-The-Latest-Tool-For-Optimizing-An-Enterprise-Strategy.pdf

Shmygol, N., Galtsova, O., Solovyov, O., Koval, V., \& Arsawan, I.W.E. (2020). Analysis of country's competitiveness factors based on inter-state rating comparisons, E3S Web of Conferences, 153, 03001.

Szewczyk, I., \& Lipianin-Zontek, E. (2019). Adaptation of business hotels to the needs of disabled tourists in Poland. Problems and Perspectives in Management, 17(4), 392-403. https://doi.org/10.21511/ppm.17(4).2019.32

Yakushev, O. (2020). Innovative Technologies in the Management of Business Processes of Enterprises of Hotel-restaurant and Tourism Industries. Restaurant and hotel consulting Innovations, 3(2), 195-208. https://doi.org/10.31866/2616-7468.3.2.2020.219696

Yukhnovska, Yu. (2019). Vplyv gotelno-restorannogo biznesu na rozvytok turystychnoyi galuzi Ukrayiny [The influence of hotel restaurant business on development of Ukrainian tourism industry]. Problemy systemnogo pidhodu v ekonomici, 3(71), 148-154, (in Ukrainian). https://doi.org/10.32782/2520-2200/2019-3-22

*** State Statistics Service of Ukraine. (2021). http://www.ukrstat.gov.ua/ 